\title{
BIOACTIVE COMPONENTS IN METHANOLIC FLOWER EXTRACT OF Ageratum conyzoides
}

\author{
${ }^{*}$ Malik F. H. Ferdosi ${ }^{1}$, Arshad Javaid ${ }^{2}$, Iqra Haider Khan ${ }^{2}$, Muhammad F. A. Fardosi ${ }^{3}$ \\ and Ayesha Munir ${ }^{4,5}$
}

DOI: https://doi.org/10.28941/pjwsr.v27i2.954

\begin{abstract}
In order to find out various bioactive compounds in flowers of Ageratum conyzoides, the dried powdered flowers were extracted in methanol and the extract was examined by GC-MS. In total, eight constituents were identified in the extract. The predominant compound in the methanol flower extract was precocene II (59.50\%). Three moderately abundant compounds including ethanone, 1-(7-hydroxy-5-methoxy-2,2-dimethyl-2H-1benzopyran-6-yl)- (9.77\%), precocene I (8.61\%) and caryophyllene $(7.60 \%)$ were also identified. Three compounds namely (E)- $\beta$-famesene $(4.23 \%), \beta$-cubebene $(4.19 \%)$ and 1 nonadecene $(4.07 \%)$ were categorized as less abundant. The eighth compound phytol was the least abundant one with peak are of $1.99 \%$. Literature survey showed that majority of the identified compounds possessed various biological properties such as aphid repellant, antioxidant, anticancer, antimicrobial and/or anti-inflammatory.
\end{abstract}

Keywords: Billygoat-weed, Flower, Methanolic extract, Natural compounds.

Citation: Ferdosi, M.F.H., I.H. Khan, A. Javaid, M.F.A. Fardosi. 2021. Bioactive Components in Methanolic Flower Extract of Ageratum conyzoides. Pak. J. Weed Sci. Res., 27 (2):181-190.

\footnotetext{
${ }^{\mathbf{1}}$ Department of Horticulture, Faculty of Agricultural Sciences, University of the Punjab, Quaid-e-Azam Campus, Lahore 54590, Pakistan

${ }^{2}$ Department of Plant Pathology, Faculty of Agricultural Sciences, University of the Punjab, Quaid-e-Azam Campus, Lahore 54590, Pakistan

${ }^{3}$ Institute of Botany, University of the Punjab, Quaid-e-Azam Campus, Lahore 54590, Pakistan

${ }^{4}$ Institute of Chemistry, University of the Punjab, Quaid-e-Azam Campus, Lahore 54590, Pakistan

${ }^{5}$ City District Government Girls High School Momin Pura Karim Park Ravi Road Lahore

*Corresponding author's email: fiaz.iags@pu.edu.pk, malikferdosi@yahoo.com
} 


\section{INTRODUCTION}

The plant kingdom is a treasure house of potent bioactive compounds that play substantial role as therapeutic agents in drug discovery (Wang et al., 2017). The products derived from plant leaves, barks, roots, flowers, and seeds have been a part of phytomedicines since ancient times (Yahya et al., 2018). Plants contain bioactive substances that include alkaloids, tannins, terpenoids, carbohydrates, flavonoids and steroids which provide definite physiological functions (Jain et al., 2019; Khan and Javaid, 2020a,b). Plants originated secondary metabolites belong to chemically diverse group of compounds with a variety of functions (Chudasama et al., 2018; Khan and Javaid, 2019). They are used widely in agriculture, veterinary, human therapy and countless scientific research (Mishra et al., 2018; Banaras et al., 2020, 2021). These compounds are the most obvious choice to examine the effective antimicrobial, anticancer, and antihepatotoxic properties (Kanwal et al., 2009; Naqvi et al., 2020). However, such products should be explored to understand their properties, efficiency, availability and safety (Xi, 2017). Many of the medicines are prepared from plants and therefore, pharmaceutical industries are largely dependent upon plant products for the preparation of medicines (Giacometti et al., 2018; Javaid et al., 2021). Presently, folk medicines are widely accepted and practiced not only in South East Asia but also in developed countries (Wangkheirakpam, 2018). Detailed research on the chemistry of plant originated products is essential, which may eventually lead to the discovery of medicines that can be used to treat several diseases (Mohammadinejad et al., 2019).

The use of modern chromatographic and spectrometric techniques such as GC-MS analysis make the exploration of bioactive compounds easier (Saucedo-Pompa et al., 2018). The most common factors that affect the extraction process are the selection of plant parts, solvent, pressure, temperature and time (Nastic et al., 2018). Plant materials can be extracted by various polar solvents and the efficiency of spectrometric techniques is mainly dependent upon the solvent type (Gallego et al., 2019; Khan and Javaid, 2020c). Methanol is the most suitable solvent used frequently to extract specific bioactive ingredients from various plants (Sobeh et al., 2018; Naqvi et al., 2019). Ageratum conyzoides is a medicinal plant belongs to Asteraceae family (Pintong et al., 2020). The plant has anti-inflammatory, pharmacological, anti-diarrheic, analgesic, insecticidal, herbicidal and antimicrobial properties (Akhtar et al., 2001; Kotta et al., 2020). Since ancient times it has been used to cure diseases such as wound dressing, uterine troubles, pneumonia, toothache, vermifuge, diarrhea, headaches, dyspnea, colic and ulcers treatment (Yadav et al., 2019). Thus, in the present study analysis of $A$. conyzoides methanolic flower extract was carried out to evaluate its bioactive phytoconstituents.

\section{MATERIALS AND METHODS}

Flowers of $A$. conyzoides were plucked during the evening time, alongside a water channel in Lahore and dried under the shade conditions. After that the dried flowers were finely ground into powder form by using the mortal and pastel. This powdered material was soaked in pure methanol for up to 15 days. Thereafter, the methanolic flower extract was filtered and shifted to the testing lab for GC-MS analysis.

Gas chromatography (GC) machine 7890B model of Agilent Technologies, USA and mass spectroscopy model 5977A that was also made in USA by Agilent, were used for the identification of phytochemicals from methanolic flower extract of $A$. conyzoides. The column used was DB 5MS with dimensions (30 $\mathrm{m} \times$ $0.25 \mu \mathrm{m} \times 0.25 \mu \mathrm{m})$; injection volume was $1 \mu \mathrm{L}$; carrier gas was helium with split less mode. Oven ramping initial temperature was $80^{\circ} \mathrm{C}$ and then raised 10 
${ }^{\circ} \mathrm{C}$ per $\min u p$ to $300{ }^{\circ} \mathrm{C}$. Inlet temperature was $280^{\circ} \mathrm{C}$ with run time 20 min. MS conditions were as mode: scan range $50-500(\mathrm{~m} / \mathrm{z})$; solvent delay time was $3 \mathrm{~min}$; MS source temperature was $230{ }^{\circ} \mathrm{C}$. Run time 20 minutes; Search library was mass hunter/NIST version 2017. Identification of chemical compounds was done by comparison of their spectra with library and arranged in the ascending order of their retention times. The relative abundance was reported by using their peak areas. Structures of compounds were drawn by ChemDraw software.

A thorough online survey was done for literature hunting to find out any previous reported bioactivity of the identified compounds from the flower extract of $A$. conyzoides. All the previously reported bioactivities of the identified compounds are presented in Table 2 by citing their references.

\section{RESULTS AND DISCUSSION}

GC-MS chromatogram of flower extract of $A$. conyzoides is presented in Fig. 1 that showed presence of eight compounds. The principal compound in this extract was 2H-1-benzopyran, 6,7dimethoxy-2,2-dimethyl- (also known by other names such asprecocene II and ageratochromene) with $59.50 \%$ peak area. Three compounds namely ethanone, 1-(7-hydroxy-5-methoxy-2,2-dimethyl-

2H-1-benzopyran-6-yl)-

$(9.77 \%)$, precocene I $(8.61 \%)$ and caryophyllene $(7.60 \%)$ were found as moderately abundant compounds. Three compounds viz. (E)- $\beta$-famesene $(4.23 \%)$, $\beta$-cubebene $(4.19 \%)$ and 1 -nonadecene $(4.07 \%)$ were ranked as less abundant ones. The compound with the least abundance was phytol with $1.99 \%$ peak area. Structures of these compounds are shown in Fig. 2 and their mass spectra are presented in Fig. 3.

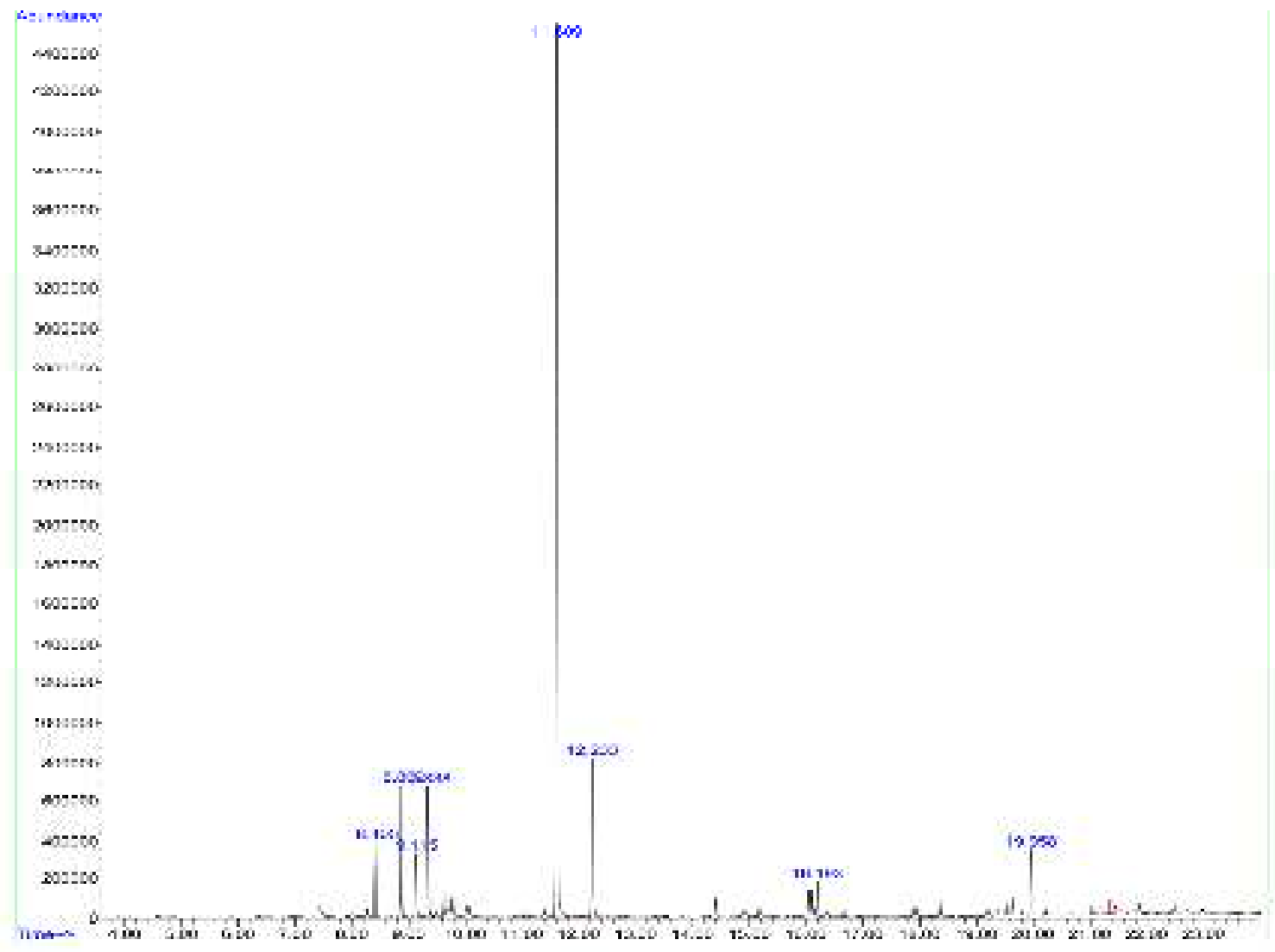

Fig. 1: GC-MS chromatogram of methanolic flower extract of Ageratum conyzoides. 


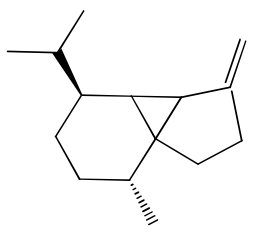

1. $\beta$-Cubebene<smiles>C=C1CC/C=C(/C)CC[C@H]2C(C)C[C@H]1C2C</smiles>

2. Caryophyllene<smiles>COc1cc2c(cc1OC)OC(C)(C)C=C2</smiles>

5. Precocene II

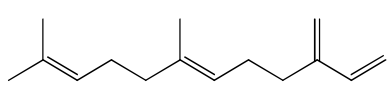

3. $(E)-\beta-$ Famesene<smiles>COc1ccc2c(c1)OC(C)(C)C=C2</smiles>

4. Precocene I<smiles>COc1c2c(cc(O)c1C(C)=O)OC(C)(C)C=C2</smiles>

6. Ethanone, 1-

(7-hydroxy-5methoxy-2,2dimethyl-2H-1benzopyran-6-yl)-<smiles>CC(=CCO)CCC(C)CCC(C)CCC(C)C</smiles>

7. Phytol
8. 1-Nonadecene

Fig. 2: Structures of identified compounds.

Table 1: Compounds in methanolic flower extract of Ageratum conyzoides.

\begin{tabular}{|c|c|c|c|c|c|}
\hline $\begin{array}{l}\text { Sr. } \\
\text { No. }\end{array}$ & Names of compounds & $\begin{array}{l}\text { Molecular } \\
\text { formula }\end{array}$ & $\begin{array}{l}\text { Molecular } \\
\text { weight }\end{array}$ & $\begin{array}{l}\text { Retention } \\
\text { time } \\
\text { (min) }\end{array}$ & $\begin{array}{l}\text { Peak } \\
\text { area } \\
(\%)\end{array}$ \\
\hline 1 & $\begin{array}{l}\text { 1H-Cyclopenta[1,3]cyclopropa[1,2] } \\
\text { benzene, octahydro-7-methyl-3- } \\
\text { methylene-4-(1-methylethyl)-, [3aS- } \\
\left.\left.\text { (3aa,3b } \beta, 4 \beta, 7 a, 7 a S^{*}\right)\right]- \\
\text { OR } \beta \text {-Cubebene }\end{array}$ & $\mathrm{C}_{15} \mathrm{H}_{24}$ & 204.35 & 8.405 & 4.19 \\
\hline 2 & Caryophyllene & $\mathrm{C}_{15} \mathrm{H}_{24}$ & 204.35 & 8.869 & 7.60 \\
\hline 3 & (E)- $\beta$-Famesene & $\mathrm{C}_{15} \mathrm{H}_{24}$ & 204.35 & 9.115 & 4.23 \\
\hline 4 & Precocene I & $\mathrm{C}_{12} \mathrm{H}_{14} \mathrm{O}_{2}$ & 190.24 & 9.338 & 8.61 \\
\hline 5 & $\begin{array}{l}\text { 2H-1-Benzopyran, 6,7-dimethoxy-2,2- } \\
\text { dimethyl- } \\
\text { OR Precocene II }\end{array}$ & $\mathrm{C}_{13} \mathrm{H}_{16} \mathrm{O}_{3}$ & 220.26 & 11.609 & 59.50 \\
\hline 6 & $\begin{array}{l}\text { Ethanone, 1-(7-hydroxy-5-methoxy- } \\
\text { 2,2-dimethyl-2H-1-benzopyran-6-yl)- }\end{array}$ & $\mathrm{C}_{14} \mathrm{H}_{16} \mathrm{O}_{4}$ & 248.27 & 12.233 & 9.77 \\
\hline 7 & Phytol & $\mathrm{C}_{20} \mathrm{H}_{40} \mathrm{O}$ & 296.5 & 16.193 & 1.99 \\
\hline 8 & 1-Nonadecene & $\mathrm{C}_{19} \mathrm{H}_{38}$ & 266.5 & 19.958 & 4.07 \\
\hline
\end{tabular}



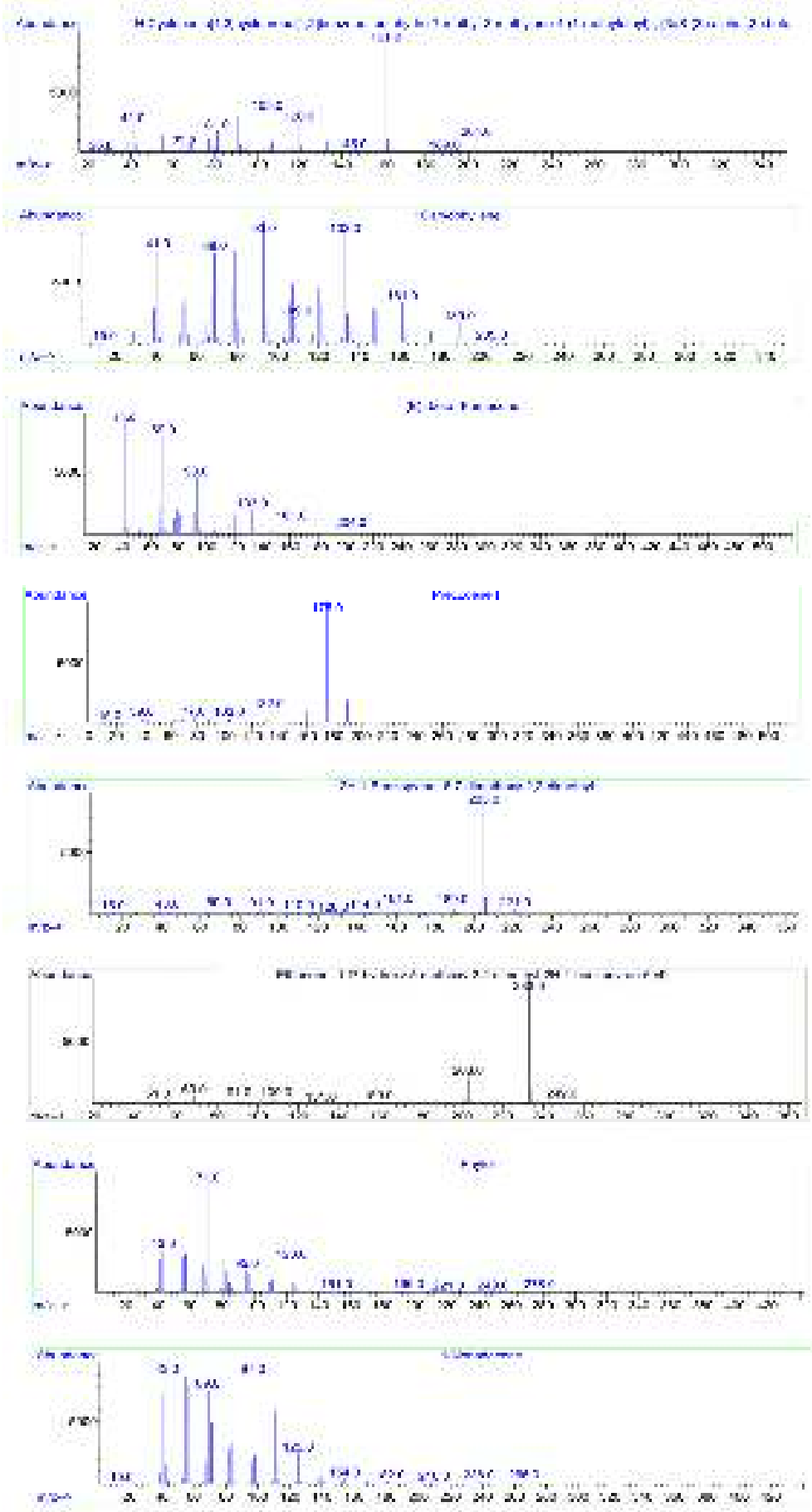

Fig. 3: Mass spectra of compounds identified in methanolic flower extract of Ageratum conyzoides. 
The literature survey showed that most of the identified compounds showed various bioactivities. The principal compound precocene II, was found in high abundance i.e. $59.50 \%$. Likewise, precocene I was identified as the third major compound in the present study with peak area of $8.61 \%$. These two compounds were also identified as the major components of essential oil of $A$. conyzoides from Barazil (Esper et al., 2015). Precocene II was the major compound in essential oil of flowers of Ageratum houstonianum (52.64\%) (Kurade et al., 2010). On the other hand, this compound was found in small quantity in essential oil of $A$. conyzoides from São Tomé and Príncipe (Martins et al., 2005). This compound is known to completely control the growth of Sclerotium rolfsii (Iqbal et al., 2004), and also inhibited the production of trichothecene (a contaminant in cereal crops having ill effects on human health) in Fusarium graminearum (Furukawa et al., 2015). Precocenes are extensively utilized as tools in experiments regarding arthropod endocrinology and are believed the model of fourth-generation pesticides as reported by Sariaslani et al. (1987). Both precocene I and II isolated from $A$. houstonianum showed strong repellant and insecticidal activities against Liposcelis bostrychophila, a common pest of stored grains (Lu et al., 2014). Precocene II also has hypoglycemic property and can change some hematopoietic elements (Adebayo et al., 2010). Derivatives of these precocenes, especially addition of an iodine in the molecules, enhanced antifeedant potential of these compounds (Szczepanik et al., 2005).

Caryophyllene was a moderately abundant compound in this study. It is a bicyclic sesquiterpene that generally found as a constituent of various essential oils. Due to its low toxicity, this naturally occurring compound is used in food industry as an antimicrobial agent (Pieri et al., 2016). It showed activity against Bacillus cereus by increasing membrane permeability that resulted in leakage of intracellular contents (Moo et al., 2020). In addition, this compound also possesses a number of other activities including antiinflammatory, anticancer and antioxidant (Dahham et al., 2015). 1-Nonadecene was a less abundant compound in the present study and has been identified in various plants and microbes with various biological activities. Yassa et al. (2009) isolated it from Rosa damascene and reported its antioxidant activity. Smaoui et al. (2012) reported this compound in Streptomyces sp. with antifungal activity against Fusarium sp. and antibacterial activity against Gram positive bacteria. (E)- $\beta$-Famesene is produced by various plant species to repel aphids (Gibson and Pickett, 1983), and by bees and ants as a defensive allomone (Crock et al., 1997). Phytol is a diterpene alcohol found a least abundant compound in the present study. It has antimicrobial property possibly due to inactivation of proteins and enzymes of the microbes (Ghaneian et al., 2015). It showed antibacterial activity against Bacillus licheniformis and reduced mortality of goldfish (Carassius auratus) by inducing immunity in the fish against this bacterial species (Saha and Bandyopadhyay, 2020). Phytol also exhibited antinociceptive effects in mice and antioxidant activity (Santos et al., 2013).

\section{Conclusion}

This study concludes that flowers of $A$. conyzoides contain a number of important bioactive compounds namely precocene I, precocene II, caryophyllene, phytol, (E)- $\beta$-famesene and 1-nonadecene which possess antimicrobial, anticancer, anti-inflammatory, aphid repellant and/or antioxidant properties. 
Table 2: Bioactivity of components of methanolic flower extract of Ageratum conyzoides.

\begin{tabular}{|c|c|c|c|}
\hline $\begin{array}{l}\text { Sr. } \\
\text { No. }\end{array}$ & Names of compounds & Bioactivity & Reference \\
\hline 1 & $\beta$-Cubebene & Antibacterial & Dakah et al. (2019) \\
\hline 2 & Caryophyllene & $\begin{array}{l}\text { Antibacterial, } \\
\text { anticancer, anti- } \\
\text { inflammatory, } \\
\text { antioxidant }\end{array}$ & $\begin{array}{l}\text { Dahham et al. } \\
\text { (2015); Moo et al. } \\
(2020)\end{array}$ \\
\hline 3 & (E)- $\beta$-Famesene & $\begin{array}{l}\text { Aphid repellants, } \\
\text { defensive } \\
\text { allomone in bees } \\
\text { and ants }\end{array}$ & $\begin{array}{c}\text { Gibson and Pickett } \\
\text { (1983); } \\
\text { Crock et al. (1997) }\end{array}$ \\
\hline 4 & Precocene I & Insect repellant & Lu et al. (2014) \\
\hline 5 & Precocene II & $\begin{array}{l}\text { Antifungal, } \\
\text { insecticidal }\end{array}$ & $\begin{array}{l}\text { Sariaslani et al. } \\
(1987) \text {; Iqbal et al. } \\
(2004)\end{array}$ \\
\hline 6 & $\begin{array}{l}\text { Ethanone, 1-(7-hydroxy-5- } \\
\text { methoxy-2,2-dimethyl-2H-1- } \\
\text { benzopyran-6-yl)- }\end{array}$ & - & - \\
\hline 7 & Phytol & Antibacterial & $\begin{array}{l}\text { Saha and } \\
\text { Bandyopadhyay } \\
\text { (2020) }\end{array}$ \\
\hline 8 & 1-Nonadecene & $\begin{array}{l}\text { Antifungal, } \\
\text { antibacterial, } \\
\text { antioxidant }\end{array}$ & $\begin{array}{l}\text { El-Sakhawy et al. } \\
\text { (1998); } \\
\text { Yassa et al. (2009); } \\
\text { Smaoui et al. (2012) }\end{array}$ \\
\hline
\end{tabular}

\section{REFERENCES CITED}

Adebayo, A.H., G.Z. Zeng, Y.M. Zhang, C.J. Ji, A.A. Akindahunsi and N.H. Tan. 2010. Toxicological evaluation of precocene II isolated from Ageratum conyzoides L. (Asteraceae) in Sprague Dawley rats. Afr. J. Biotecnol. 9: 29382944.

Akhtar, N., A. Javaid and R. Bajwa. 2001. Herbicidal activity of aqueous extract of Cirsium arvense and Ageratum conyzoides against weeds of wheat. Pak. J. Biol. Sci. 4 (11): 1364-1367.

Banaras, S., A. Javaid and I.H. Khan. 2020. Potential antifungal constituents of Sonchus oleraceous against Macrophomina phaseolina. Int. J. Agric. Biol. 24(5): 1376-1382.

Banaras, S., A. Javaid and I.H. Khan. 2021. Bioassays guided fractionation of Ageratum conyzoides extract for the identification of natural antifungal compounds against Macrophomina phaseolina. Int. J. Agric. Biol. 25 (4): 761-767.

Chudasama, R.G., N.J. Dhanani, R.M. Amrutiya, R. Chandni, G. Jayanthi and K. Karthikeyan. 2018. Screening of selected plants from semi-arid region for its phytochemical constituents and antimicrobial activity. J. Pharmacog. Phytochem. 7: 2983-2988.

Crock, J., M. Wildung and R. Croteau. 1997. Isolation and bacterial expression of a sesquiterpene synthase cDNA clone from peppermint (Mentha piperita L.) that produces the aphid alarm pheromone (E)- $\beta$ farnesene. Proc. Natl. Acad. Sci. 94: 12833-12838.

Dahham, S., Y. Tabana, M. Iqbal, M. Ahamed, M. Ezzat, A. Majid and A. Majid. 2015. The anticancer, 
antioxidant and antimicrobial properties of the sesquiterpene $\beta$ caryophyllene from the essential oil of Aquilaria crassna. Molecules 20:11808-11829.

Dakah, A., S. Zaid, M. Suleiman and M. Dakka. 2019. Chemical components and antibacterial activities of essential oil of wild, in vitro and acclimatised plants of Ziziphora tenuior L. Int. Food Res. J. 26: 723-730.

El-Sakhawy, F.S., M.E. El-Tantawy, S.A. Ross and M.A. El-Sohly.1998. Composition and antimicrobial activity of the essential oil of Murraya exotica. Flavour. Frag. J. 13: 59-62.

Esper, R.H., E. Goncalex, R.C. Felicio and J.D. Felicio. 2015. Fungicidal activity and constituents of Ageratum conyzoides essential oil from three regions in São Paulo state, Brazil. Arq. Inst. Biol. 82: 1-4.

Furukawa T., N. Sakamoto, M. Suzuki, M. Kimura, H. Nagasawa and S. Sakuda. 2015. Precocene II, a trichothecene production inhibitor, binds to voltagedependent anion channel and increases the superoxide level in mitochondria of Fusarium graminearum. PloS ONE 10: e0135031.

Gallego, R., M. Bueno and M. Herrero. 2019. Sub-and supercritical fluid extraction of bioactive compounds from plants, food-by-products, seaweeds and microalgae- an update. Trends Analyt. Chem., 116: 198-213.

Ghaneian, M.T., M.H. Ehrampoush, A. Jebali, S. Hekmatimoghaddam and $M$. Mahmoud. 2015. Antimicrobial activity, toxicity and stability of phytol as a novel surface disinfectant. Environ. Health Eng. Manage. J. 2: 1316.

Giacometti, J., D.B. Kovacevic, P. Putnik, D. Gabric, T. Bilusic, G. Kresic and A.R. Jambrak. 2018. Extraction of bioactive compounds and essential oils from mediterranean herbs by conventional and green innovative techniques: A review. Food Res. Int., 113: 245-262.
Gibson, R.W. and J.A. Pickett.1983 Wild potato repels aphids by release of aphid alarm pheromone. Nature 302: 608-609.

Iqbal, M.C.M., U.L.B. Jayasasinghe, H.M.T.B. Herath, K.B. Wiljesekara and Y. Fujimoto. 2004. A fungistatic chromene from Ageratum conyzoides. Phytoparasitica 32: 119-126.

Jain, C., S. Khatana and R. Vijayvergia. 2019. Bioactivity of secondary metabolites of various plants: a review. Int. J. Pharm. Sci. Res. 10: 494-498.

Javaid, A., S.F. Naqvi and I.H. Khan. 2021. Ethyl acetate extract of Chenopodium murale root, a source of bioactive compounds. Pak. J. Weed Sci. Res. 27(1): 93-100.

Kanwal, Q., I. Hussain, H.L. Siddiqui andA. Javaid 2009. Flavonoids from mango leaves with antibacterial activity. J. Serb. Chem. Soc. 74(12): 1389-1399.

Khan, I.H. and A. Javaid. 2019. Antifungal, antibacterial and antioxidant components of ethyl acetate extract of quinoa stem. Plant Prot. 3(3): 125-130.

Khan, I.H. and A. Javaid. 2020a. Anticancer, antimicrobial and antioxidant compounds of quinoa inflorescence. Adv. Life Sci. 8(1): 6872.

Khan, I.H. and A. Javaid. 2020b. Antifungal activity and GC-MS analysis of $n$-butanol extract of quinoa leaves. Bangladesh J. Bot. 49(4): 1045-1051.

Khan, I.H. and A. Javaid. 2020c. Comparative antifungal potential of stem extracts of four quinoa varieties against Macrophomina phaseolina. Int. J. Agric. Biol. 24(3): 441-446.

Kotta, J.C., A. Lestari, D.S. Candrasari and M. Hariono. 2020. Medicinal effect, in silico bioactivity prediction, and pharmaceutical formulation of Ageratum conyzoides L.: a review. Scientifica 2020: Article 6420909.

Kurade, N.P., V. Jaitak, V.K. Haul and O.P. Sharma. 2010. Chemical composition and antibacterial activity of essential 
oils of Lantana camara, Ageratum houstonianum and Eupatorium adenophorum. Pharm. Biol. 48: 539544.

Lu, X.N., X.C. Liu, and Z.L. Liu. 2014. Isolation of insecticidal constituents from the essential oil of Ageratum houstonianum Mill. against Liposcelis bostrychophila Badonnel. J. Chem. 2014: Article 645687.

Martins, A.P., L.R. Salgueiro, M.J. Gonçalves, R. Vila, S. Cañigueral, F. Tomi. 2005. Essential oil composition and antimicrobial activity of Ageratum conyzoides from S. Tomé and Príncipe. J. Essent. Oil Res. 17: 239-242.

Mere, C.A., J.C. Ifemeje and K. Ifeanyi. 2021. Assessment of toxicologic and radical scavenging potentials of methanol extract of Ageratum conyzoides. J. Med. Plant 9: 1-5.

Mishra, A.P., M. Sharifi-Rad, M.A. Shariati, Y.N. Mabkhot, S.S. Al-Showiman, A. Rauf and M. Iriti. 2018. Bioactive compounds and health benefits of edible Rumex species - a review. Cell. Mol. Biol. 64: 27-34.

Mohammadinejad, R., H. Maleki, E. Larrañeta, A.R. Fajardo, A.B. Nik, A. Shavandi and kV.K. Thakur. 2019. Status and future scope of plant-based green hydrogels in biomedical engineering. Appl. Mater. Today 16: 213-246.

Moo, C-L, S-K. Yang, M-A. Osman, M.H. Yuswan, J-Y. Loh and K-S. Lai. 2020. Antibacterial activity and mode of action of $\beta$-caryophyllene on Bacillus cereus. Pol. J. Microbiol. 69: 49-54.

Naqvi, S.F., A. Javaid and M.Z. Qureshi. 2019. Evaluation of antifungal potential of leaf extract of Chenopodium murale against Fusarium oxysporum f. sp. lycopersici. Planta Daninha 37: Article e019199050.

Naqvi, S.F., I.H. Khan and A. Javaid. 2020. Hexane soluble bioactive components of Chenopodium murale stem. Pak. J. Weed Sci. Res. 26(4): 425-432.

Nastic, N., J. Svarc-Gajic, C. DelerueMatos, M.F. Barroso, C. Soares, M.M. Moreira, and M. Radojkovic. 2018.
Subcritical water extraction as an environmentally-friendly technique to recover bioactive compounds from traditional Serbian medicinal plants. Ind. Crop Prod. 111: 579-589.

Pieri, F.A., M.C.C. Souza, L.L.R. Vermelho, M.L.R. Vermelho, P.G. Perciano, F.S. Vargas, A.P.B. Borges, V.F. da VeigaJunior and M.A.S. Moreira. 2016. Use of $\beta$-caryophyllene to combat bacterial dental plaque formation in dogs. BMC Vet. Res. 12(1): Article 216.

Pintong, A.R., J. Ruangsittichai, S. Ampawong, K. Thima, P. Sriwichai, N. Komalamisra and S. Popruk. 2020. Efficacy of Ageratum conyzoides extracts against Giardia duodenalis trophozoites: an experimental study. BMC Complement. Med. Ther. 20: 1-9.

Saha, M. and P.K. Bandyopadhyay. 2020. In vivo and in vitro antimicrobial activity of phytol, a diterpene molecule, isolated and characterized from Adhatoda vasica Nees. (Acanthaceae), to control severe bacterial disease of ornamental fish, Carassius auratus, caused by Bacillus licheniformis PKBMS 16. Microb. Pathog. 141: 103977.

Santos, C.C.M.P., M.S. Salvadori, V.G. Mota and D.P. de Sousa. 2013. Antinociceptive and antioxidant activities of phytol in vivo and in vitro models. Neuroscie. J. 2013: Article 949452.

Sariaslani, F.S., L.R. McGee and D.W. Ovenall. $1987 . \quad$ Microbial transformation of precocene II: oxidative reactions by Streptomyces griseus. Appl. Environ. Microbiol. 53: 1780-1784.

Saucedo-Pompa, S., J.A. Torres-Castillo, C. Castro-López, R. Rojas, E.J. Sánchez-Alejo, M. Ngangyo-Heya and G.C.G. Martínez-Ávila. 2018. Moringa plants: bioactive compounds and promising applications in food products. Food Res. Int. 111: 438450.

Smaoui, S., F. Mathieu, L. Elleuch, Y. Coppel, G. Merlina, I. Karray-Rebai and L. Mellouli. 2012. Taxonomy, 
purification and chemical characterization of four bioactive compounds from new Streptomycessp. TN256 strain. World J. Microbiol. Biotechnol. 28: 793-804.

Sobeh, M., F.S. Youssef, A. Esmat, G. Petruk, A.H. El-Khatib, D.M. Monti and M. Wink. 2018. High resolution UPLCMS/MS profiling of polyphenolics in the methanol extract of Syzygium samarangense leaves and its hepatoprotective activity in rats with $\mathrm{CCl}_{4}$-induced hepatic damage. Food Chem. Toxicol. 113: 145-153.

Szczepanik, M., R. Obara, A. Szumny, B. Gabryś, A. Halarewicz-Pacan, J. Nawrot and C. Wawrzeńczyk. 2005. Synthesis and insect antifeedant activity of precocene derivatives with lactone moiety. J. Agric. Food Chem. 53: 5905-5910.

Wang, M., J. Wang, Y. Zhou, M. Zhang, Q. Xia, W. Bi and D.D.Y. Chen. 2017. Ecofriendly mechanochemical extraction of bioactive compounds from plants with deep eutectic solvents. ACS Sustain. Chem. Eng. 5: 6297-6303.
Wangkheirakpam, S. 2018. Traditional and folk medicine as a target for drug discovery. In: Natural Products and Drug Discovery, Elsevier. pp. 29-56.

$X i$, J. 2017. Ultrahigh pressure extraction of bioactive compounds from plants a review. Crit. Rev. Food Sci. Nutr. 57: 1097-1106.

Yadav, N., S.A. Ganie, B. Singh, A.K. Chhillar and S.S. Yadav. 2019. Phytochemical constituents and ethnopharmacological properties of Ageratum conyzoides L. Phytother. Res. 33: 2163-2178.

Yahya, N.A., N. Attan and R.A. Wahab. 2018. An overview of cosmeceutically relevant plant extracts and strategies for extraction of plant-based bioactive compounds. Food Process. 112: 69-85.

Bioprod.

Yassa, N., F. Masoomi, S.E.R. Rankouhi and A. Hadjiakhoondi. 2009 Chemical composition and antioxidant activity of the extract and essential oil of Rosa damascena from Iran, population of Guilan. DARU J. Pharm. Sci. 3:175180. 